\title{
The potential and economic viability of solar photovoltaic power in Ghana
}

\author{
Samuel Asumadu-Sarkodie (1) and Phebe Asantewaa Owusu (1) \\ Middle East Technical University, Northern Cyprus Campus
}

\begin{abstract}
In this study, the potentiality and economic viability of solar photovoltaic (PV) in Ghana was assessed using RETScreen software. $5 \mathrm{MW}$ of grid-connected solar PV power system using SunPower SPR-320E-WHT-D PV module can be harnessed from Navrongo, Bawku, Wa, Tema, Bolgatanga, Axim, Salaga, Kintampo, Kete Krachi, Tamale, Hohoe, Koforidua, Ejura, Takoradi, Bole, Sunyani, Bibiani, Cape coast, Prestea, and Akuse, which requires US $\$ 17,752,179$ of investment capital and $25,313 \mathrm{~m}^{2}$ of land for PV installation. The potential of $5 \mathrm{MW}$ grid-connected PV development for Accra, Kumasi, Wenchi, and Tafo are limited. However, there are solar PV energy potentials for low-capacity PV modules for these locations. Investing in solar photovoltaic technology is capital intensive in a developing country like Ghana. However, Government's effort to provide incentives like subsidies and creating the economic environment for private sector investment will boost investment possibilities of renewable energy in Ghana, which can help in curbing the recent power outages and load shedding, thereby increasing productivity and economic resilience.
\end{abstract}

\section{KEYWORDS}

Ghana; grid-connected;

renewable energy;

RETScreen; solar

photovoltaic; solar radiation

\section{Introduction}

Energy has become one of the greatest challenges facing humanity in the twenty-first century (Chen 2011). However, solar energy is freely available, abundant everywhere in the world, and proven as economical in terms of energy source for many solar applications. Energy from the sun, which the earth receives, is gargantuan and long-lasting to the extent that the total energy consumed annually by the entire world is supplied in a time as short as half an hour (Rekioua and Matagne 2012). According to Bauer (2015), the life expectancy of the sun, which is the reservoir of solar radiation, amounts to 4.5 billion years, which makes it effectively inexhaustible. The most incredible thing is that the sun is the cleanest, renewable, and sustainable energy source, which emits neither greenhouse gases nor toxic waste via its exploitation.

Global warming has become one of the most significant challenges facing the world in the coming centuries. The Intergovernmental Panel on Climate Change has concluded based on a $90 \%$ confidence that the current warming in the global climate is a result of human-induced activities such as burning of fossil fuels (Sustainability 2014). Although there is an uncertainty in the prediction of the exact effects of climate change, nonetheless the development and utilization of sustainable energy sources like solar energy is an essential component of the mitigation and adaptation of climate change (Sustainability 2014). Industrialized countries like the United States, the United Kingdom, and Germany are leaving the era of fossil-nuclear based energy supply behind, by embracing photovoltaic (PV) to play a significant role in their future sustainable power production (Wirth and Schneider 2015). 
Presently there is a recognition of the need to use solar energy both nationally and internationally, which has led to a steady growth in the worldwide demand for solar electric power systems (RETScreen ${ }^{\circledast}$ International), and the technical exploitation of solar energy is expanding significantly due to increasing population and the decline of fossil fuel based electricity generation during the last decades. Because of this, there is an emergence of a global paradigm shift initiated by International Energy Agency (IEA), to promote energy security through; a collective response to physical disruptions in fossil fuel based energy supply, by the provision of authoritative research, and analysis on all forms of renewable energy resources. This global action will ensure the following: a reliable, affordable, accessible, quality, quantity and clean energy provision in such a way as to reduce greenhouse gas emissions that contributes to climate change (International Energy Agency 2014).

The major global energy challenges are threefold; securing energy supply to meet growing demand, providing everybody with access to energy services and curbing energy's contribution to climate change. Access to energy has a linkage with the improvement of human development. Nonetheless, 1.3 billion people, which is equivalent to $10 \%$ of the world's population, lack access to electricity. Out of this, $22 \%$ are living in developing countries with almost $97 \%$ of this percentage without access to electricity living in sub-Saharan Africa and developing Asia (International Energy Agency).

Ghana is one of the most successful countries in sub-Saharan Africa in improving access to electricity, having shown long-term and strong political commitment since the establishment of its National Electrification Scheme in 1989 (International Energy Agency). However, Ghana has been battling with load shedding and power outages in the past few years due to its overdependence on hydroelectric power supply, which dates back to the 1960s; hydroelectric power supply has been supplemented with thermal power, still that is not enough for achieving availability and accessibility of energy.

Electricity from PV systems has achieved global prominence and competitiveness in the energy market (Breyer and Gerlach, 2013; Dufo-López and Bernal-Agustín, 2013). The recent sharp drop in the cost of generating electricity using PV has triggered an increasing global demand and rapid investment in PV power plants (Grossmann et al., 2015) regardless of the intermittence and seasonal variability of solar energy which appears to be the main obstacle impeding its dependability.

Several research studies have been done on photovoltaic in many countries owing to its electricity technology, which has become the fastest growing electricity technology (Grossmann et al., 2015) within the last few decades. Harder and Gibson (2011) studied the cost and benefits (financial feasibility) of large-scale solar PV power production in Abu Dhabi, United Arab Emirates using RETScreen modeling software to predict energy production and greenhouse gas emissions reductions. Recently, Obeng and Evers (2010) have assessed the impacts of public solar PV electrification on rural micro-enterprises in Ghana and Bawakyillenuo (2012) have investigated the deconstruction of the dichotomies of solar PV dissemination trajectories in Ghana. However, extensive research analysis has been performed within the scope of assessing photovoltaic potentials in Ghana.

In this work, the economic viability and potentiality of photovoltaic in Ghana has been analyzed using the RETScreen modeling software. This study will bring to light, the solar photovoltaic energy resource potential in Ghana: how it can be harnessed and incorporated into the energy portfolio to help the recent energy crisis. This study has been done in 24 locations, namely Accra, Akuse, Axim, Bawku, Bibiani, Bole, Bolgatanga, Cape coast, Ejura, Hohoe, Kete krachi, Kintampo, Koforidua, Kumasi, Navrongo, Prestea, Salaga, Sunyani, Tafo, Takoradi, Tamale, Tema, Wa, and Wenchi.

\section{Materials and methods}

In order to assess the economic viability and potentiality of photovoltaic in Ghana, a grid-connected $\mathrm{PV}$ power potential in 24 different locations in Ghana were considered in this study with a $5 \mathrm{MW}$ solar PV system in each location. RETScreen modeling software by National Resource Canada has been employed to analyze and assess the energy production, energy production cost and savings, 
The final publication is available at Taylor \& Francis via http://dx.doi.org/10.1080/15567036.2015.1122682

ENERGY SOURCES, PART A: RECOVERY, UTILIZATION, AND ENVIRONMENTAL EFFECTS

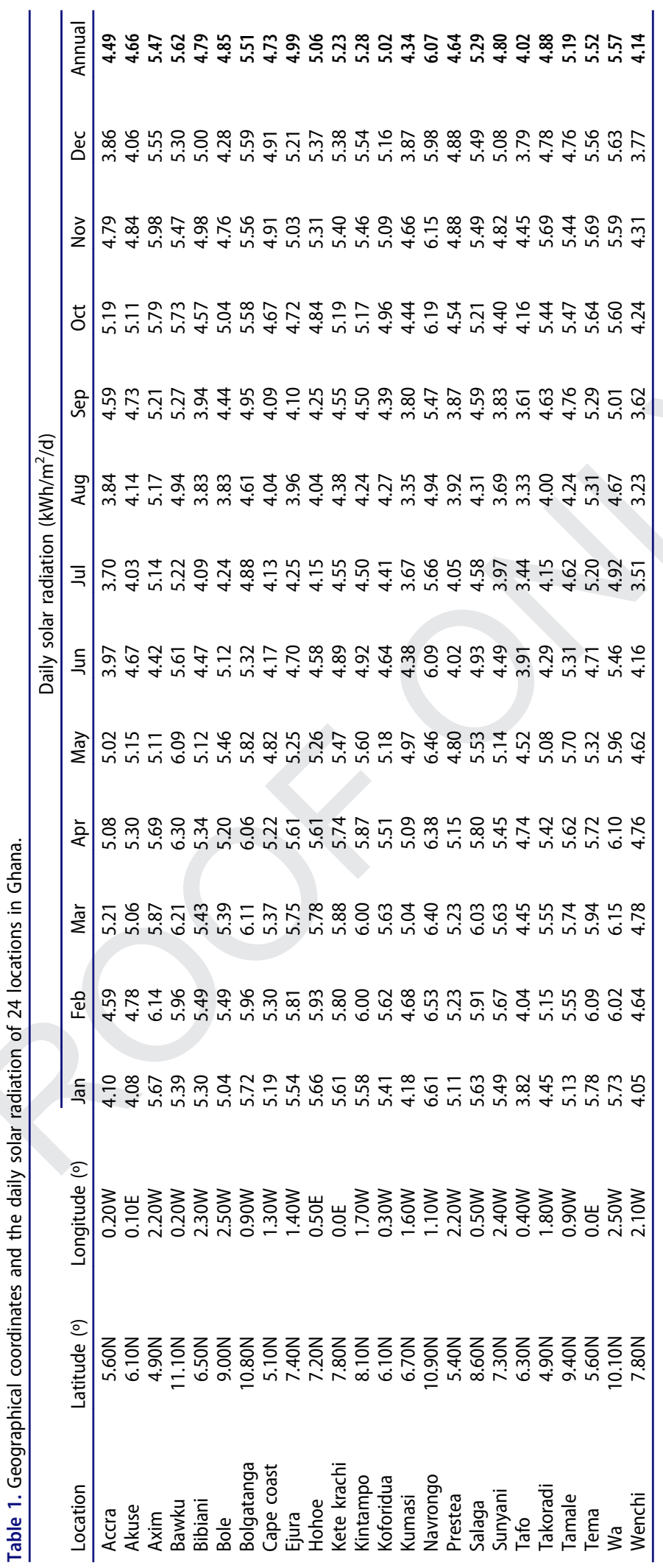


Table 2. Specifications of PV power system (SunPower, 2010).

\begin{tabular}{lll}
\hline Item & \multicolumn{1}{c}{ Parameter } & Unit \\
\hline Photovoltaic material & \multicolumn{1}{c}{ Mono-Si } \\
Manufacturer & SunPower & \\
Module & SPR-320E-WHT-D & \\
Module area & 1.62 & $\mathrm{~m}^{2}$ \\
Power capacity & 0.32 & $\mathrm{~kW} / \mathrm{unit}$ \\
Total power capacity & 5,000 & $\mathrm{~kW}$ \\
Peak power $(+5 /-3 \%)\left(P_{\max }\right)$ & 320 & $\mathrm{~W}$ \\
Efficiency $(\eta)$ & 19.60 & $\%$ \\
Rated voltage $\left(V_{\text {mpp }}\right)$ & 54.70 & $\mathrm{~V}$ \\
Rated current $\left(I_{\text {mpp }}\right)$ & 5.86 & $\mathrm{~A}$ \\
Open circuit voltage $\left(V_{\text {OC }}\right)$ & 64.80 & $\mathrm{~V}$ \\
Short circuit voltage $\left(I_{\mathrm{SC}}\right)$ & 6.24 & $\mathrm{~A}$ \\
Maximum system voltage $(U L)$ & 600 & $\mathrm{~V}$ \\
Temperature coefficients $($ Power $(P))$ & -0.38 & $\% / \mathrm{K}$ \\
Voltage $\left(V_{\text {OC }}\right)$ & -176.60 & $\mathrm{mV} / \mathrm{K}$ \\
Current $\left(I_{\text {SC }}\right)$ & 3.50 & $\mathrm{~mA} / \mathrm{K}$ \\
NOCT & $45+/-2$ & ${ }^{\circ} \mathrm{C}$ \\
Weight & 18.60 & $\mathrm{~kg}$ \\
Dimension $(L \times W \times H)$ & $32 \times 155 \times 128$ & $\mathrm{~mm}$ \\
Temperature & -40 to +80 & ${ }^{\circ} \mathrm{C}$ \\
\hline
\end{tabular}

greenhouse gas emission reduction, life cycle costs, operation and maintenance cost, and financial feasibility of the PV power system. The RETScreen software uses the monthly average values of global solar radiation on horizontal surface, the monthly average temperature, the sun-tracking settings to estimate the energy export to the grid, and the plant capacity factor.

Input data from NASA global solar radiation database for the selected locations has been used in this study. For each location, a fixed slope at the latitude angle and facing south has been considered. The azimuth angle was taken as zero for all locations (Kebede 2015). Table 1 shows the geographical coordinates of 24 locations including their daily solar radiation. The selected locations are based on the availability of data from NASA global solar radiation database and their accessibility to the national grid. The annual daily horizontal solar radiation from the 24 locations in Ghana ranges from 4 to $7 \mathrm{kWh} / \mathrm{m}^{2} / \mathrm{d}$, as depicted in Table 1 .

\section{Proposed PV power project}

SunPower SPR-320E-WHT-D PV module has been selected for the proposed grid-connected 5 MW solar PV power system. The model was selected because it provides today's highest PV efficiency and performance (Green et al., 2015) by utilizing 96 back-contact solar cells that delivers a total panel conversion efficiency of $19.6 \%$ and provides outstanding energy delivery per peak power watt (Sunpower 2015). Table 2 presents the specifications of the PV power system measured at Standard Test Conditions (STC): irradiance of $1,000 \mathrm{~W} / \mathrm{m}^{2}, \mathrm{AM} 1.5$, and cell temperature $25^{\circ} \mathrm{C}$. For each of the $5 \mathrm{MW}$ grid-connected PV system, 15,625 solar PV panels are required (is calculated by dividing the total watt peak rating by the PV module peak output rating) with $25,313 \mathrm{~m}^{2}$ of area for PV installation. For grid connection, an inverter is required for the PV power system; we considered 5 units of ABB PVS800-57 model central inverters with 1,000 kW capacity. ABB central inverter model was selected because of its high total efficiency level (98.8\%); "optimized and accurate system control and a maximum power point tracking (MPPT) algorithm together with high efficiency power converter design that ensures that maximum energy is delivered to the power distribution network from the PV modules" (ABB 2015). Even though the 5 units of ABB PVS800-57 model central inverters with 1,000 kW capacity will provide 5,000 kW capacity, nonetheless, previous studies (Besarati et al., 2013, Kebede 2015) consider 4,750 kW as the capacity and $96 \%$ efficiency for the inverter. In this study, $4,750 \mathrm{~kW}$ capacity and $98.80 \%$ efficiency is considered. 


\section{Financial analysis model}

Economic analysis for the PV power project is as crucial as capacity factor for decision-making bodies in both public and private sector investments. The RETScreen Clean Energy Project Analysis modeling software is capable of performing financial analysis based on financial parameters such as project lifetime, inflation rate, debt interest rate, energy cost, greenhouse gas emission credit, energy cost escalation rate, etc. Feed-in-tariffs for grid-connected solar PV system in Ghana cost $64.4 \mathrm{GHp} /$ $\mathrm{kWh}$ (US\$ 200/MWh) (Magazine 2015). The total initial cost of the PV power system is US $\$ 17,114,354$ while Operation and Maintenance cost is US\$637,825; in total, the cost of a $5 \mathrm{MW}$ grid-connected fixed PV power system in this study cost US\$17,752,179. In order to calculate the cost of electricity, the following assumptions have been made. Table 3 presents an extensive summary of the financial input parameters used for cost analysis.

\section{Results and discussion}

The capacity factor of a PV power system is vital to stakeholders, both public and private during decision-making for investment in this renewable energy potential.

In Table 4, the potentiality and economic viability of $5 \mathrm{MW}$ PV power system in 24 locations in Ghana are given. The second column in Table 4 depicts the capacity factor for fixed array. The mean capacity factor for fixed array is $18.9 \%$.

The third column in Table 4 depicts the pre-tax internal rate of return (IRR) of the proposed PV power project. Navrongo has the highest pre-tax IRR of $24.2 \%$ while Tafo has the lowest pre-tax IRR of $2.3 \%$. Pre-tax IRR helps to rank potential projects according to their order of priority (TheFreeDictionary.com 2015). Assuming all factors are equal, in the event of limited resources, Navrongo will be the best option to choose since it has the highest pre-tax IRR value.

The fourth column in Table 4 depicts the simple payback period of the proposed PV power project. Tafo has the longest simple payback period (12.5 years) while Navrongo has the shorter simple payback period (7.3 years). A shorter simple payback period means a desirable investment.

The fifth column in Table 4 depicts the equity payback period of the proposed PV power project. Tafo has the longest equity payback period (19.2 years) while Navrongo has a shorter equity payback period (5.0 years). Equity payback period is the time required to recover the equity investment out of pre-tax cash flows reflecting inflation and debt payments (RETScreen). The shorter the equity payback period, the more profitable and attractive the project.

The sixth column in Table 4 depicts the net present value of the proposed PV power project. Net present value is used to determine the present value of an investment. A positive net present value

Table 3. Summary of financial input parameters for cost analysis.

\begin{tabular}{lll}
\hline Item & \multicolumn{1}{l}{ Value } \\
\hline Installed capital cost & US\$2,039/kW & (M. Solar, 2015) \\
Feasibility study, development and engineering & $0.6 \%$ of initial cost & (Kebede, 2015) \\
Power system cost & US\$2,487,942 (24.4\% of initial cost) \\
Balance of system cost & $3 \%$ of initial cost & (Kebede, 2015) \\
Miscellaneous/contingency fund & $10 \$ / \mathrm{kW} /$ year & \\
Operation and maintenance cost & US\$102,565 & (Kebede, 2015) \\
Inverter replacement cost & $70 \%$ & (El-Shimy, 2009) \\
Debt ratio & $10 \%$ & \\
Debt interest rate & 15 years & \\
Debt term & $5 \%$ & \\
Energy cost escalation rate & $10 \%$ & \\
Discount rate & $10 \%$ & \\
Inflation rate & $24 \%$ & (BoG)) \\
Interest rate & 25 years & ((NREL), 2011) \\
Project lifetime & $18 \%$ & (International Energy Agency, 2014) \\
Transmission and distribution losses & & \\
\hline
\end{tabular}




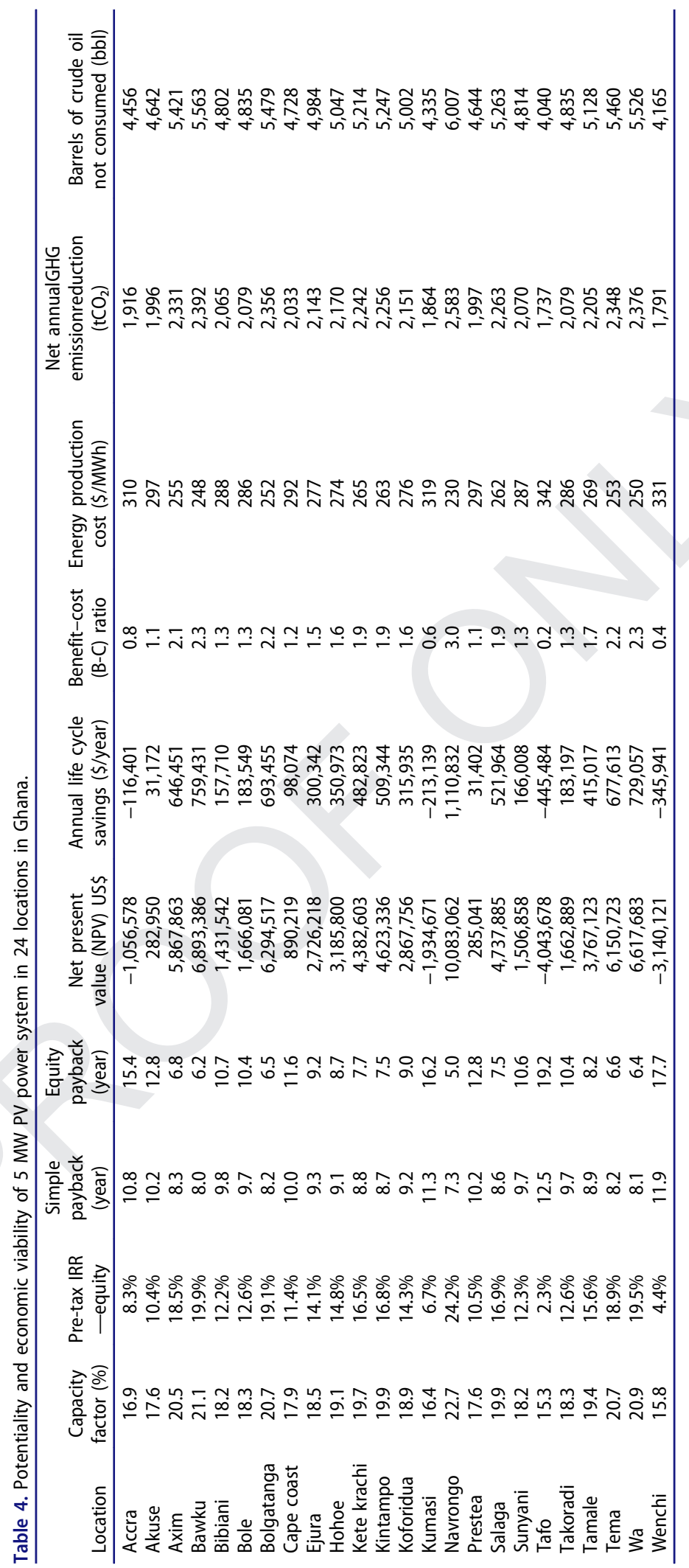


shows that the proposed PV power projects in Navrongo, Bawku, Wa, Tema, Bolgatanga, Axim, Salaga, Kintampo, Kete Krachi, Tamale, Hohoe, Koforidua, Ejura, Takoradi, Bole, Sunyani, Bibiani, Cape coast, Prestea, and Akuse are profitable and as such worth investing.

The seventh column in Table 4 depicts the annual life cycle savings of the proposed PV power project. Excluding Accra, Kumasi, Wenchi, and Tafo, which show a negative annual life cycle savings, the remaining locations have positive savings irrespective of inflation rate, interest rate, and taxes.

The eighth column in Table 4 depicts the benefit-cost ratio of the proposed PV power project. The benefit-cost ratios for the proposed PV power project in 20 locations excluding: Accra, Kumasi, Wenchi, and Tafo, show a positive value greater than 1 , which gives a signal that the benefits of the proposed PV power project outweigh its costs.

The ninth column in Table 4 depicts the energy production cost of the proposed PV power project. The lowest cost of electricity is $\$ 0.23 / \mathrm{kWh}$, which occurs in Navrongo while the highest cost of electricity is $\$ 0.34 / \mathrm{kWh}$, which occurs in Tafo. The cost of electricity in this study seems to be higher than the cost of grid-connected solar PV in Ghana, which is $\$ 0.20 / \mathrm{kWh}$ (Commission 2014). Consequently, reducing the interest rate and other financial parameters assumed in the study makes the proposed PV power project more attractive and less cost intensive.

The tenth and eleventh columns in Table 4 depict the net annual greenhouse gas (GHG) emission reduction due to the proposed PV power project and comparison of the GHG emission reduction with barrels of crude oil not consumed. Each of the 24 locations plays a role in reducing GHG emissions, which is equivalent to over 4,000 barrels of crude not consumed. Africa's role in global GHG emissions may be relatively limited; however, its involvement in the issue is prominent (International Energy Agency 2014). In particular, temperatures across the African continent are projected to rise faster than the global average (James and Washington 2013).

\section{Conclusions}

In this study, the potentiality and economic viability of solar photovoltaic in 24 locations in Ghana were assessed using RETScreen Clean Energy Project Analysis modeling software. Locations were selected based on the availability of data from NASA global solar radiation database and their accessibility to the national grid. SunPower SPR-320E-WHT-D PV module was selected for the proposed grid-connected $5 \mathrm{MW}$ solar PV power system because of its highest PV efficiency and performance in today's PV industry. A summary of findings from the study is as follows:

- A grid-connected $5 \mathrm{MW}$ solar PV power system can be harnessed from Navrongo, Bawku, Wa, Tema, Bolgatanga, Axim, Salaga, Kintampo, Kete Krachi, Tamale, Hohoe, Koforidua, Ejura, Takoradi, Bole, Sunyani, Bibiani, Cape coast, Prestea, and Akuse.

- A grid-connected $5 \mathrm{MW}$ solar PV power system requires US\$17,752,179 of investment capital and $25,313 \mathrm{~m}^{2}$ of land for PV installation.

- The potential for 5 MW grid-connected PV development for Accra, Kumasi, Wenchi, and Tafo is limited. However, there are solar PV energy potentials for low capacity PV modules that can be utilized in these locations.

- The cost of electricity in this study seems to be higher than the cost of grid-connected solar PV in Ghana, which is $\$ 0.20 / \mathrm{kWh}$. Consequently, reducing the interest rate and other financial parameters assumed in the study makes the proposed PV power project more attractive and less cost intensive.

Investing in solar photovoltaic technology is capital intensive in developing countries like Ghana. However, government's effort to provide incentives like subsidies and creating the economic environment for private sector investment will boost investment possibilities of renewable energy 
in Ghana, which can help in curbing the recent power outages and load shedding, thereby increasing productivity and economic resilience.

\section{ORCID}

Samuel Engin Asumadu-Sarkodie (D) http://orcid.org/0000-0001-5035-5983

Phebe Owusu (D) http://orcid.org/0000-0001-7364-1640

\section{References}

ABB. 2015. Solar Inverters: ABB central inverters, PVS800 -100 to $1000 \mathrm{~kW}$.

Bauer, G. 2015. Photovoltaic Solar Energy Conversion. : Springer.

Bawakyillenuo, S. 2012. Deconstructing the dichotomies of solar photovoltaic (PV) dissemination trajectories in Ghana, Kenya and Zimbabwe from the 1960s to 2007. Energy Policy 49:410-421.

Besarati, S. M., Padilla, R. V., Goswami, D. Y., and Stefanakos, E. 2013. The potential of harnessing solar radiation in Iran: Generating solar maps and viability study of PV power plants. Renewable Energy 53:193-199.

Breyer, C., and Gerlach. A. 2013. Global overview on grid-parity. Prog. Photovoltaics Res. Appl. 21:121-136. DOI: 10.1002/pip.1254.

Chen, C. J. 2011. Physics of solar energy. : John Wiley \& Sons.

Commission, Public Utility Regulation. 2014. Feed In Tarrifs. Available at: http://www.purc.com.gh/purc/sites/default/ files/fit_2014.pdf.

Dufo-López, R., and Bernal-Agustín, J. L. 2013. Photovoltaic grid parity in Spain. In: Advances in Mechanical and Electronic Engineering. : Springer, pp. 235-239.

Green, M. A., Emery, K., Hishikawa, Y., Warta, W., and Dunlop, E. D. 2015. Solar cell efficiency tables (Version 45). Prog. photovoltaics Res. Appl. 23:1-9.

Grossmann, W., Grossmann, I., and Steininger, K. W. 2015. Solar electricity supply isolines of generation capacity and storage. Proc. Natl. Acad. Sci. USA 112:3663-3668. DOI: 10.1073/pnas.1316781112.

Harder, E., and Gibson, J. M. 2011. The costs and benefits of large-scale solar photovoltaic power production in Abu Dhabi, United Arab Emirates. Renewable Energy 36:789-796. DOI: 10.1016/j.renene.2010.08.006.

International Energy Agency. 2014. World Energy Outlook Special Report. In Africa Energy Outlook, edited by International Energy Agency.

James, R., and Washington, R. 2013. Changes in African temperature and precipitation associated with degrees of global warming. Clim. change 117:859-872.

Kebede, K. Y. 2015. Viability study of grid-connected solar PV system in Ethiopia. Sustainable Energy Technol. Assess. 10:63-70. DOI: 10.1016/j.seta.2015.02.003.

Magazine, P. V. 2015. Solar to play key role in Ghana's US\$230 million renewable energy program. Available at: http:// m.pv-magazine.com/news/details/beitrag/solar-to-play-key-role-in-ghanas-us230-million-renewable-energy-pro gram_100019480/.

Obeng, G. Y., and Evers, H. D. 2010. Impacts of public solar PV electrification on rural micro-enterprises: The case of Ghana. Energy Sustainable Dev. 14:223-231. DOI: 10.1016/j.esd.2010.07.005.

Rekioua, D., and Matagne, E. 2012. Photovoltaic Applications Overview. In: Optimization of Photovoltaic Power Systems. : Springer, pp. 1-29. .

RETScreen. 2015. Retscreen - Introduction - Speaker's Notes. Available at: http://www.retscreen.net/ang/speakers_ notes_overview_intro.php.

RETScreen ${ }^{\star}$ International. Clean Energy Project Analysis: Retscreen ${ }^{\circledR}$ Engineering \& Cases Textbook. Small Hydro Project Analysis Chapter.

Sunpower. 2015. Facts about Solar Technology from SunPower.

Sustainability, UCLA Institute of the Environment and. 2014. A Feasibility Analysis of Installing Solar Photovoltaic Panels Over California Water Canals. 2015 (29th July). Accessed June, 2014.

TheFreeDictionary.com. 2015. Internal rate of return. Available at: http://financial-dictionary.thefreedictionary.com/ internal+rate+of+return.

Wirth, H., and Schneider, K. 2015. Recent facts about photovoltaics in Germany. 